\title{
CONCEPÇÕES BASILARES E PRÁTICAS DOCENTES EM AULAS DE LÍNGUA PORTUGUESA
}

\author{
Maria Teresa Tedesco Vilardo Abreu*
}

\begin{abstract}
RESUMO: O desafio da educação básica, em pleno século XXI, é fazer, de fato, nossos estudantes saírem da escola dominando conhecimentos básicos. Desde sempre ouvimos que os estudantes brasileiros não sabem nada; as avaliações de larga escala, em diferentes resultados ao longo do ano, atestam o senso comum: as dificuldades extremas na formação discente. No meio de toda essa discussão, as disciplinas Língua Portuguesa e Matemática lideram em resultados aquém do desejável dos estudantes. Não se podem negar os esforços, ainda que canhestros, engendrados pelo MEC e por diferentes secretarias de educação. A pergunta crucial é por que os resultados brasileiros continuam denunciando as sérias dificuldades dos estudantes. Longe de querer responder a esta crucial pergunta, como professora de Língua Portuguesa e formadora de professores, também me debruço sobre esta grave problematização. Tenho como hipótese central que não se trata, apenas, de uma questão metodológica, ou de falta de material didático. Esses são atingidos pela ausência clara de pressupostos teóricos que sustentam as práticas de ensinar e de aprender língua portuguesa na formalidade da sala de aula. Tomando essa hipótese como ponto de partida para as reflexões que desejo propor neste artigo, pretendo discutir os equívocos encontrados em diferentes práticas didáticas, considerando conceitos linguísticos fundamentais denominados como conceitos basilares, a saber: língua e linguagem, texto e gêneros. Postula-se que, apesar do grande e importante avanço das teorias linguísticas, esses conceitos não chegam à ponta: a sala de aula básica, ao professor do ensino básico.
\end{abstract}

PALAVRAS-CHAVE: Conceitos basilares; Interação social; Práticas de sala de aula; Teorias linguísticas.

\section{Introdução}

Ainda em pleno século XXI, estamos discutindo, no Brasil, a eficiência da escola na formação dos estudantes da escola básica. Reiteradamente, ouvimos notícias sobre nossas dificuldades, o quanto os estudantes da escola básica saem despreparados para enfrentarem a vida em termos de conhecimentos e de prosseguimento dos estudos. A escola não forma o básico para os estudantes decidirem que caminhos tomar para a continuação da escolaridade, depois de treze anos obrigatórios nos bancos escolares. Evidentemente, não estou

* Doutora em Linguística pela Universidade Federal do Rio de Janeiro (UFRJ). Professor Associada da Universidade do Estado do Rio de Janeiro (Uerj). 
contabilizando a perda dos estudantes pela evasão escolar. Fato é, entretanto, que os estudantes, aqueles que conseguem chegar ao final dos estudos, não dominam os conhecimentos básicos necessários nas diferentes disciplinas. Corroborando os objetivos desse dossiê, concentro-me em reflexões sobre o ensino de língua portuguesa na escola básica, pensando sobre o que se faz e o que se deveria fazer para o desenvolvimento das capacidades de leitura e de escrita.

Não é novidade que nossos colegas de diferentes áreas - Ciências, História, Geografia, Matemática, por exemplo - ficam estupefatos frente às dificuldades de leitura e de escrita dos estudantes. Há, sem dúvida, neste assombro, um viés de responsabilização ao professor de língua portuguesa, o que, defende-se, é um dos entraves do ensino, já que, nessa visão, predomina um olhar de ensino e de aprendizagem, voltado para a individualidade do saber, somente. Defende-se a construção social deste saber, o que implica, de imediato em diferentes mediadores no processo de aprendizagem da língua.

Por outro lado, não se pode negar a existência de diferentes políticas educacionais. A questão, entretanto, é, em que medida essas políticas alcançam os docentes que atuam em sala de aula nas escolas brasileiras; se alcançam, as medidas pedagógicas atingem, efetivamente, seus objetivos finais, quais sejam, fazer os estudantes aprenderem?

A premissa principal defendida é que existem concepções teóricas basilares para o desenvolvimento do processo de ensinar e de aprender. Ter conhecimento destas concepções influencia diretamente as escolhas metodológicas que o docente fará para a construção de seu fazer didático. Neste sentido, postula-se que não se pode pensar em metodologias de ensino e de aprendizagem, sem que se pense em concepções basilares que sustentam estas metodologias, sejam elas quais forem as escolhidas.

Estas concepções são, inicialmente, voltadas para a área da linguagem porque é o fio condutor, já que o fazer da sala de aula se faz por meio da linguagem oral e da escrita, sempre e necessariamente. Por isso, esta premissa contempla não só os docentes de língua portuguesa que atuam diretamente ensinando a língua materna, mas também os colegas docentes de todas as áreas que usam a língua materna para "fazer a educação". 
Considerando este quadro geral, temos o fito de discutir as concepções basilares; de apresentar, de forma breve, as políticas educacionais mais recentes, de desenhar o que predomina em sala de aula. Por fim, apresentar estratégia metodológica que abrigue as concepções teóricas defendidas.

\section{Concepções basilares}

Uma primeira concepção fundamental está pautada na visão vygotskiana de que a aprendizagem é construída na interação de sujeitos cooperativos cujos objetivos são comuns, o que significa dizer que o processo de aprendizagem ocorre de "fora para dentro". É social, primeiramente, para, em seguida, ser individual, local. Nesse processo de interação, os mediadores, no nosso caso professor/ estudante; estudante/ estudante, têm de ter objetivos comuns. Essa visão muda, por exemplo, a forma de apresentação de um texto em salas de aulas de língua portuguesa, atividade corriqueira em nossas práticas pedagógicas.

Para que o professor de língua Portuguesa faz, executa, apresenta uma atividade de leitura em sala de aula? Há inúmeras razões para isso. A prática pedagógica, entretanto, me leva a afirmar que essa metodologia é utilizada para cumprir um "ritual primário das aulas de língua portuguesa": ensinar a ler, ensinar a interpretar.

Dessa resposta advém, em seguida, uma pergunta importante: $O$ que é ensinar a ler? Ler, antes de tudo, é um ato de compreensão do que o autor tem intenção de dizer (ou do que o autor do texto diz.). Esse ato de compreensão pressupõe, necessariamente, conhecer o contexto de produção do texto. Este conhecer implica em saber o que o leitor sabe sobre o tema de que trata o texto, sobre o autor que escreve o texto, sobre o momento sociohistórico de que trata o texto.

Kleiman nos diz que

Isto implica que é na interação, isto é, na prática comunicativa em pequenos grupos, com o professor ou com seus pares, que é criado o contexto para que aquela criança que não entendeu o texto o entenda. (KLEIMAN, 2007, p. 10) 
Esta primeira concepção toma, portanto, como base que o aprendizado de uma língua, passando pelo desenvolvimento da capacidade de leitura, da escrita e do uso da gramática da língua, está calcada na perspectiva da prática social, o que remete a mediações entre pares e, também remete a conhecimentos de outros textos e de outras leituras, começando pela leitura de mundo, prática que o sujeito faz do que está em seu entorno. Entende-se que todo o sujeito traz consigo esta bagagem sociocultural porque está posto no mundo. Quando lemos, acionamos nosso sistema de valores, de crenças e de atitudes advindos das práticas sociais em que estamos todos inseridos. As práticas escolares de linguagem vão ampliar estas práticas sociais, permitindo aos estudantes fazerem novas correlações, ampliando seu(s) conhecimento(s).

Desta concepção de interação social advém a segunda concepção. Trata-se do conceito de linguagem. Neste aspecto, muitas têm sido as contribuições. Retomo, entretanto, a visão de Geraldi (2012, p. 41) sobre os diferentes conceitos de linguagem. Para o autor, fundamentalmente, há três conceitos diferentes sobre linguagem que podem ser assim apontados.

a) A linguagem é a expressão do pensamento. Esta é uma concepção advinda da tradição gramatical greco-romana que perpassa toda a idade média. Na verdade, somente foi posta em xeque com o advento das teorias linguísticas postuladas por Saussure, no início do século XX. Essa concepção preconiza que a linguagem é produzida no interior da mente humana. Neste sentido, o pensamento vem antes da linguagem, sendo monológica e individualizada porque não considera os fatores externos à linguagem, ou seja, fatores externos ao pensamento.

A crítica contumaz que se pode fazer a esse conceito é de um teor excludente porque tem, em seu âmago, a premissa de que há pessoas que não pensam porque não podem, não sabem se expressar. Essa visão é altamente excludente ao se pensar na escrita como forma de expressão, por exemplo, considerando tantos e tantos estudantes, em todos os níveis de ensino, com dificuldades na escrita, coloquialmente, dificuldades de colocar as 
ideias no papel. Também tem este viés excludente, ao se pensar no alto número de analfabetos no Brasil, bem como no altíssimo nível de analfabetos funcionais no sistema escolar brasileiro. Evidente que não se pode aceitar esse conceito.

b) A linguagem como instrumento de comunicação. Nesse conceito, linguagem/ língua são entendidas como código, havendo, também, uma confusão entre os dois. Linguagem é definida como um sistema de códigos imutáveis que transmite mensagens de um emissor para um receptor. Neste sentido, tem-se uma visão passiva daqueles que integram o processo de comunicação, em que alguém emite uma mensagem e alguém espera para recebê-la. Não há interação no processo de comunicação. Para Travaglia,

[...] a língua é vista como um código, ou seja, como um conjunto de signos que se combinam segundo regras, e que é capaz de transmitir uma mensagem, informações de um emissor a um receptor. Esse código deve, portanto, ser dominado pelos falantes para que a comunicação seja efetivada. (TRAVAGLIA, 1997. p. 22)

Ora, o entendimento semântico de código é de algo restrito, algo a que reduzidamente se tem acesso. Trata-se de uma visão inconcebível para o entendimento do que seja linguagem, altamente excludente, pois significa dizer que somente algumas pessoas têm acesso à língua, dominam-na. Quem são essas pessoas? Aquelas que são privilegiadas culturalmente, excluindo, por conseguinte, uma grande massa não escolarizada. Evidente, mais uma vez, que não se pode concordar com essa visão, tendo-se a consciência do alto nível de exclusão que o conceito prega.

c) A linguagem como forma de interação. Nesse conceito, linguagem é vista como um lugar de interação social. É por meio da linguagem que agimos sobre o outro. Emissor e Receptor não estão estanques, isolados de si, não são passivos no processo de comunicação. Ao contrário, são sujeitos que (Inter)agem no processo, "constituindo compromissos e vínculos que não existiam antes da fala." (GERALDI, 2012. p. 41).

Neste sentido, há ações pela linguagem. Os sujeitos dialogam, trocam informações, ideias, mobilizam-se, discutem, transformam, agem, atuam sobre o outro. Esse conceito de linguagem se ajusta ao postulado por Vygotsky no que concerne à aprendizagem. Para esse 
autor, aprendizagem é interação porque está calcada na linguagem. O desenvolvimento do indivíduo e, por conseguinte, da humanidade resultam de um processo sócio-histórico cujo desenvolvimento ocorre de um viés de intersubjetividade (de fora, exógena) para o intrassubjetivo (endógena). Por isso, o aspecto sociocultural é tão importante na construção do conhecimento.

A palavra-chave é interação social, o que implica dizer que o desenvolvimento do indivíduo ocorre por meio da relação com o outro, com o mundo. Vemos nesse conceito uma forte correlação com a primeira concepção aqui apresentada, decisiva para o postulado defendido.

Essa segunda concepção está fortemente relacionada ao conceito de língua, nossa terceira concepção basilar. Sem tecer maiores detalhes, o conceito de linguagem como expressão de pensamento está muito ligado ao conceito de língua da tradição gramatical, ou seja, gramática como “ a arte de escrever bem.”, língua como normatização; a linguagem como instrumento de comunicação está estreitamente ligada à teoria da comunicação, que trouxe um novo olhar para o ensino, propondo, por exemplo, no cerne da discussão de língua as diferentes funções da linguagem (cf. teoria de Jacobson). Neste sentido, representa um avanço. Considera, entretanto, uma relação passiva entre os atores do processo de comunicação, o que não soa positivo. Além disso, é preciso registrar que esse segundo conceito se configura como linha principal na maioria dos materiais didáticos produzidos, especificamente, no que concerne às diretrizes pedagógicas dirigidas aos docentes. Entretanto, na prática didática, quer seja na organização de exercícios de compreensão de textos, de escrita propriamente dita ou nos exercícios de gramática, o que se vivencia é o distanciamento deste conceito, havendo uma forte aproximação ao conceito greco-romano de língua como forma de expressão do pensamento.

O conceito de língua vinculado ao conceito de linguagem como forma de interação nos leva a pensar em uma visão de língua como descrição, pois se está sobrelevando a questão da enunciação, a questão discursiva, de aceitação das diferentes possibilidades de língua, uma relação centrada na linguagem em se pôr no mundo: um querer dizer, a quem dizer, por que dizer, a partir de nossas diferentes vivências sociais. 
O exposto até aqui nos permite afirmar a existência de um quarto conceito basilar: o conceito de texto. Independente das vertentes teóricas, como falantes da língua, sabe-se que a comunicação entre as pessoas ocorre por meio de textos de diferentes extensões, é verdade, mas jamais por meio de frases descontextualizadas ou isoladas, fora de um contexto discursivo. Nas nossas práticas sociais vivenciamos esta realidade. As teorias de base funcionalista abordam o texto como elemento basilar, diferentemente das teorias estruturalistas que ignoram o texto como elemento essencial da interação. (Aliás, desconsideram a existência da interação!).

Neste horizonte, o conceito de texto, entendido como parte intrínseca do processo de interação, valoriza dois conjuntos fundamentais: o dos aspectos linguísticos propriamente ditos e o dos aspectos sociocomunicativos, estabelecendo, assim, uma relação construtiva entre a estrutura textual e a função social do texto.

Há dois aspectos que merecem destaque nesta concepção. O primeiro é que este olhar para o conceito de texto levou os estudiosos a entenderem que os conhecimentos inerentes ao repertório linguístico não são elementos de per si e também não são suficientes para compor um conjunto de regras previamente determinado. O signo somente toma forma quando está inserido no contexto, está posto discursivamente. $\mathrm{Na}$ verdade, esses conhecimentos são (re)construídos a partir das negociações entre os falantes da língua nas diferentes situações de comunicação em que estão inseridos. Esses aspectos linguísticos, melhor dizendo, as escolhas linguísticas vão se realizando, considerando os propósitos comunicativos e as intenções do produtor do texto. Logo, esta concepção de texto privilegia a dialogicidade no processo de comunicação, sendo o texto, o lugar próprio da interação. De acordo com Koch,

[...] o texto passa a ser visto como próprio lugar de interação e os interlocutores como sujeitos ativos que - dialogicamente- nele se constroem e nele são construídos. A produção da linguagem constitui a atividade interativa altamente complexa de produção de sentidos [...], mas que requer não apenas a mobilização de um vasto conjunto de saberes, mas, sobretudo, a sua reconstrução no momento da interação verbal. (grifos da autora) $(\mathrm{KOCH}, 2014$. p. 31) 
O outro aspecto relevante na concepção de texto é que vigora nas práticas escolares de língua materna a presença do texto como abordagem composicional do ensino. Impera, entretanto, uma concepção centrada na perspectiva de texto como repositório de informações a serviço dos conteúdos a serem ensinados ao longo dos diferentes anos de escolaridade. Dificilmente, a perspectiva é de texto como lugar de interação. Essa perspectiva revela um olhar para o texto, considerando tanto o seu contexto interno quanto o externo. Os exercícios propostos e a abordagem em sala de aula, em grau alto de predominância, propõem um estudo não sobre o texto e suas variáveis e seus contextos, mas sobre os signos que lá estão, sobre as relações de seleção e de combinação destes signos, deixando de lado o olhar para o texto como lugar de interação.

Considerando o conceito de texto, chega-se à quinta concepção basilar cujo foco central é o conceito de gênero, tão importante quando se pensa em linguagem. Os gêneros discursivos materializam o discurso, visto que "envelopam" o que se diz, considerando o propósito comunicativo do enunciador. E' uma condição imanente do discurso. O conceito de gênero existe desde a Grécia Antiga com Platão e Aristóteles. Na metade século XX, entretanto, o conceito é tomado em nova dimensão por Mikhail Bakhtin (2011) que propõe uma classificação dos gêneros baseada nas relações sociais estabelecidas pelo homem por meio da linguagem. Por isso, neste viés, a intenção comunicativa do enunciador é tão importante. É impossível separar os aspectos culturais, os sociológicos e os ideológicos de cada ato de linguagem em que nós, falantes, estamos incessantemente inseridos nas nossas práticas sociais. Para o autor, estes atos de linguagem seguem determinados padrões postos à disposição dos sujeitos falantes, que ordenam, delimitam e definem a estrutura desses atos.

Para Bakhtin (2011, p. 261-262), todos os campos da atividade humana estão ligados à linguagem e cada esfera de comunicação apresenta "seus tipos relativamente estáveis de enunciados, denominados gêneros do discurso". O que é importante entender é a dinamicidade destes gêneros, em consonância com a dinamicidade da linguagem ou dos atos comunicativos. Esses se modificam da mesma forma que se modificam as relações sociais. Por isso, são “tipos relativamente estáveis”, já que variam de acordo com os propósitos e 
as intenções comunicativas, mas mantém características específicas nas atividades humanas de linguagem que, também, são variáveis. Neste sentido, há uma gama de gêneros discursivos que existem enquanto, digamos, houver necessidade do gênero para um determinado ato comunicativo.

O referido autor afirma que existem duas grandes categorias de gêneros: os denominados primários (simples) e os secundários (complexos). Esse grau de complexidade entre as duas categorias diz respeito às situações específicas do ato de comunicação e suas diferentes complexidades, devido às questões culturais. Pode-se comparar, por exemplo, uma conversa entre dois amigos em um bar e a escrita de uma carta a um amigo que está longe, morando em outra cidade. Concordamos que existem condições de produção diferentes e graus de complexidade, também, diferentes entre as duas situações de comunicação. Na primeira, há uma maior proximidade entre os dois interlocutores, há mais informalidade; na segunda, o distanciamento é maior, o que exigirá dos interlocutores uma capacidade de comunicação escrita, de forma clara e coerente, a fim de evitar qualquer ambiguidade, que não poderá ser sanada de imediato como poderia acontecer na situação dos amigos no bar.

A inserção do conceito de gênero nos curricula e nas práticas pedagógicas não pode ser considerada um modismo. Trata-se, na verdade, de uma concepção basilar do que seja e do como se compõe a atividade de linguagem humana. Ao tomar como ponto de partida esses conceitos, devemos, nas práticas pedagógicas, adotar metodologias compatíveis com os princípios abaixo destacados, considerando que (i) as atividades de linguagem são dinâmicas; (ii) as diferentes disciplinas que formam o currículo básico se constituem em diferentes atividades de linguagem, com suas características próprias, estilos diferentes e conteúdos temáticos variados, por isso se materializam em gêneros textuais diferentes, inseridos que estão em uma atividade discursiva maior, que é a escola. 
Figura 1 - Concepções basilares

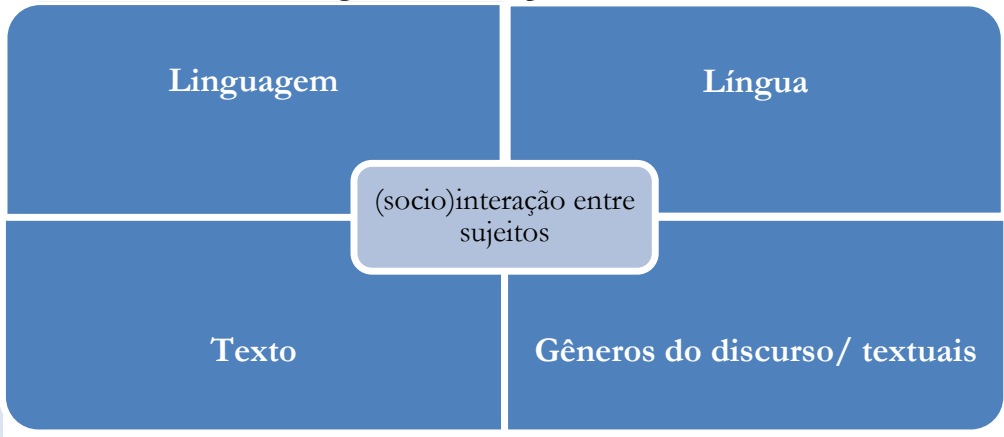

Fonte: Elaborado pela autora

\section{Pequena Incursão sobre os documentos curriculares oficiais: Parâmetros Curricu- lares Nacionais (PCN) e Base Nacional Comum Curricular (BNCC)}

Não se pretende apresentar uma análise exaustiva dos dois documentos curriculares. Considera-se essencial revisitar os dois textos na perspectiva das concepções basilares anteriormente apresentadas, com intuito de afirmar que essas circulam como fundamentação teórica para o ensino de língua portuguesa na escola básica desde o primeiro documento.

Há muito se vem discutindo na área de educação o impacto que os PCN causaram (ou vêm causando) no ensino. Muitas críticas foram feitas desde a sua publicação em 1998. No que concerne à abordagem da/ na disciplina Língua Portuguesa, o referido documento está centrado na valorização da pluralidade de usos linguísticos e suas variedades, considerando diversos gêneros orais e escritos. O que se pode emergir desta perspectiva teórica, por seu turno, é que os Parâmetros se propõem a uma formação crítica dos estudantes na escolaridade básica, tornando-os conscientes acerca de uma condição sine qua non da língua, a sua heterogeneidade. Fato é que as ideias apresentadas não são novas, a exemplo da discussão concernente aos pressupostos da linguística textual. Autores tais como Fávero \&Koch (1983), Geraldi (1997), apenas, para citar alguns, há muito sugerem uma abordagem mais produtiva no ensino da Língua Portuguesa. Além disso, sabe-se que influenciaram não 
só a construção teórica dos PCN, mas também vêm influenciando o cenário de pesquisas da área de Letras, bem como a formação de professores.

Santos adverte, entretanto, que

[...] a reação dos profissionais de educação nem sempre é de concordância com as mudanças engendradas pelos Parâmetros. Por deficiências na sua formação e/ou falta de atualização, o professor se confunde em meio a termos e teorias que não domina, como o conceito de Gênero Textual, por exemplo. (SANTOS, 2009, p. 60)

Desta forma, o que pudemos ver, ao longo destas décadas, nas escolas, não em sua totalidade, mas, em grande maioria, foi uma admirável dificuldade na organização do currículo programático. Elencam-se conteúdos estanques, ignorando a estreita relação existente entre o ensino da gramática e os usos da língua; ignora-se que a língua só ocorre por meio da materialidade textual, manifestada nos diferentes e ilimitados gêneros que concretizam o dizer dos interlocutores (repetindo, pela materialidade textual) nas duas grandes modalidades de língua: oral e escrita. Em contrapartida, as orientações dirigidas aos docentes nos livros didáticos apresentam o discurso coadunado às teorias linguísticas modernas. A fala dos professores e dos coordenadores vão ao encontro destes pressupostos. $\mathrm{Na}$ verdade, o currículo de Língua Portuguesa desconsidera a abordagem produtiva da língua, que repercute as vivências das práticas de linguagens em suas diferentes situações discursivas.

Ao contrário desta perspectiva, viu-se um alargamento desses conteúdos, considerando, por exemplo, os elementos de coesão, os gêneros textuais como (mais) tópicos teóricos, a serem explicados, analisados, estudados para fins de avaliação, distanciando-se, assim, dos termos como pressupostos, como concepção basilar para o entendimento da língua e para o desenvolvimento das habilidades dos estudantes para análise e para compreensão de textos.

O encaminhamento dado às construções dos conteúdos programáticos das escolas básicas, dos currículos escolares centrou-se na "didatização" das teorias em voga, pelo menos, aquelas mais latentes, deixando-se de lado o cerne e a concepção fundamental da linguagem, do ato de linguagem imanente do ser humano. Ainda se acrescenta que, em 
nossa área de ensino e de aprendizagem - a Linguagem -, lidamos como objeto de estudos com a própria linguagem, as ações linguageiras. Ter a consciência desse "cruzamento de interesses" é entender que não ensinamos, em sala de aula, uma língua diferente daquela que usamos no nosso dia a dia nas diferentes situações de comunicação em que estamos inexoravelmente inseridos.

Pode-se afirmar ser este o grande nó do ensino de Língua Portuguesa. Esta tomada de consciência se concretiza nas escolhas teóricas. Delas advêm as escolhas metodológicas. Defende-se, de forma veemente, que é impossível pensar em métodos de ensino, metodologias de aprendizagem, profícuos, que atinjam seus objetivos, caso o docente não tenha absoluta clareza do caminho teórico que deseja seguir (de suas escolhas teóricas). Por isso, adota-se a expressão escolha (s) teórico-metodológica(s), que traz a implicação de um para um, ou seja,

Figura 2 - Processos de ensino e de aprendizagem

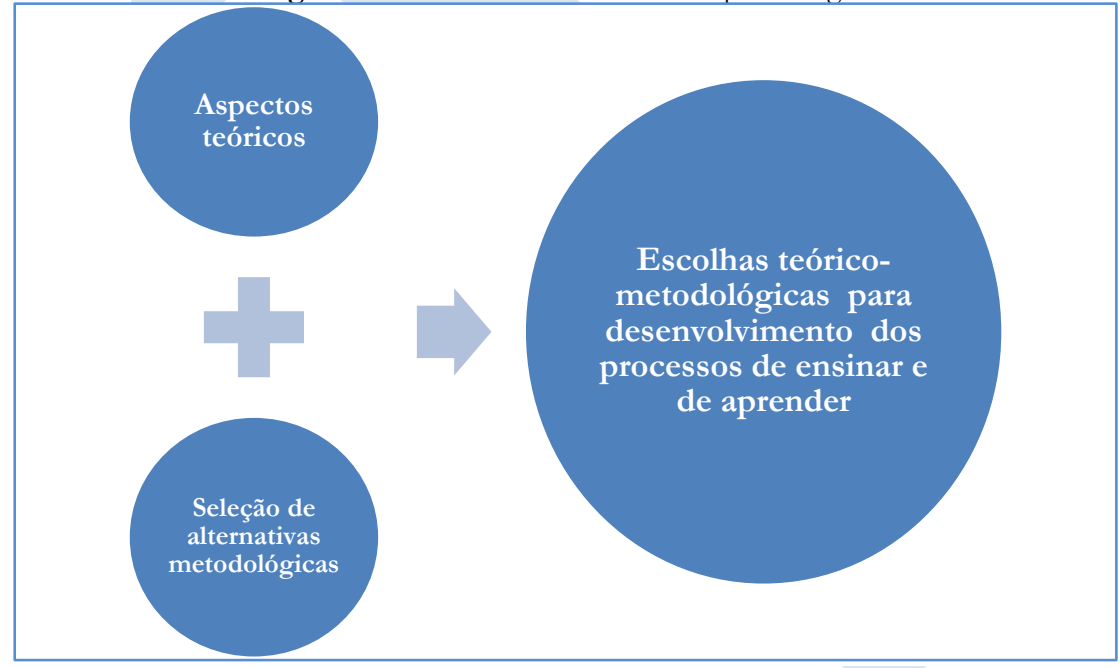

Fonte: Elaborada pela autora 
Após tantos anos de vigência dos PCN, diante de um mundo com novas exigências em termos de comunicação, e conscientes de que a escola não vem atendendo a seu objetivo maior que é desenvolver os conhecimentos dos estudantes, há todo um movimento, sem dúvida, político, para a promulgação de uma base comum curricular, a BNCC, que passou por muitas discussões, reescritas e chega às escolas brasileiras com a missão de tornar este processo mais produtivo.

Caminhos foram escolhidos e traçados. Não se tem a pretensão, neste momento, de se fazer uma análise crítica da BNCC. Claro que como qualquer documento, a BNCC poderia traçar outros caminhos, outras visões. Cabe, no entanto, aferir as perspectivas tomadas para o ensino de Língua Portuguesa. Neste caso, não se vai aprofundar a visão expressa na BNCC do ponto de vista da literatura, aporte que merece muita atenção, pois pode (parece) ter havido certa desconsideração ao texto literário.

Como era a expectativa, não houve mudanças contundentes naquilo que denominamos, neste texto, de concepções basilares. A exemplo dos PCN, as concepções fundamentam os caminhos que devem ser tomados para o desenvolvimento de habilidades de leitura e de escrita dos estudantes da escola básica. Estão especificadas as habilidades a serem desenvolvidas ao longo da escolaridade, havendo um continuum necessário entre os anos do ensino básico. Defende-se que é bem positivo este posicionamento. Há, como era de se esperar, um forte investimento nos gêneros textuais a serem apresentados, incluindo diferentes gêneros concernentes à área da tecnologia.

Dentre as tantas questões que se colocam diante deste novo desafio, uma delas não será igual ao que ocorreu com a implantação dos PCN? - é a quantidade de gêneros textuais indicados por ano de escolaridade na BNCC. Um dos recorrentes questionamentos de docentes e de coordenadores é de como o currículo de Língua Portuguesa poderá contemplar tantos gêneros textuais a serem trabalhados em cada ano. Não é esta a única dificuldade com a qual se depara neste momento. Entende-se, entretanto, que esta dificuldade questionada revela, de forma metonímica, o entendimento oriundo da leitura da BNCC no que tange ao ensino de nossa língua materna. É possível que esta mesma leitura se estenda às demais áreas de conhecimento. 
Não se pode entender que a BNCC liste conteúdos de ensino. Portanto, acreditase que não seja intenção, no referido documento, arrolar uma lista infindável de gêneros textuais a serem apresentados aos estudantes em cada ano de escolaridade, estudados exaustivamente e "cobrados" em diferentes avaliações. Essa perspectiva não se coaduna com o exposto na primeira seção deste artigo, porque põe por terra o princípio imanente da língua, conforme já justificado.

Retomando Bakhtin (2011), em relação aos gêneros, o autor afirma que cada esfera da atividade humana apresenta gêneros que se configuram segundo características específicas, tais como o estilo, ou seja, a forma que usamos as estruturas linguísticas, a estrutura composicional, isto é, o que modela a arquitetura daquele gênero e o conteúdo temático, quer dizer, o tema desenvolvido no texto e como este é desenvolvido.

Esta será a nossa tarefa como professores da escola básica e dos cursos de formação de professores: na organização do currículo programático, considerando a língua como forma de interação, utilizando os elementos das concepções basilares, vamos organizar estes gêneros, tendo como elemento primordial as características linguístico- discursivas que distanciam os gêneros entre si e os aproximam também. Portanto, saímos da perspectiva de um olhar de conteúdos para abraçarmos, convictamente, a perspectiva discursiva do ensino e tudo que isto significa. A consequência disso será um importante olhar para o efetivo desenvolvimento de habilidade de leitura, de escrita, de usos da língua.

Esse novo currículo programático dará lugar para uma abordagem da língua materna, considerando as diferentes situações linguageiras em que nos inserimos, o texto como a efetiva materialidade da língua, a existência de propósitos comunicativos dos enunciadores, que utilizam, para atingir seus propósitos, os recursos linguísticos disponíveis no sistema da língua.

Tem-se consciência de que o texto da BNCC foi produzido em um contexto de alta complexidade quando estavam articulados diversos eventos como o golpe institucional contra a Presidente Dilma Rousseff; as pressões do movimento "Escola sem Partido"; as confusões entre conceitos importantes nas diferentes áreas, bem como o aligeiramento, por pressões governamentais para que a Base fosse legitimada pelo Congresso Nacional, 
em detrimento de uma aprovação pelo CNE. Evidentemente, todo este contexto tem impactos sobre as propostas da BNCC. No que tange à área da linguagem, estão garantidos os pressupostos básicos. Os gêneros são de natureza ilimitada. Logo, cabe ao docente a conscientização dos usos da língua, materializados em gêneros, denominados por Bakhtin de secundários, porque envolvem um grau mais elevado de análise e reflexão sobre a língua, tanto nas atividades de leitura quanto nas atividades de produção de texto.

Por fim, não se tem a pretensão neste artigo de demonstrar facilidades para as abordagens aqui apresentadas. Não é fácil!! Não obstante, de fato, acredita-se que esta tomada de consciência real é o largo passo do início da caminhada para a reorganização do currículo programático e um novo fazer da sala de aula de língua portuguesa, propiciando o efetivo desenvolvimento do conhecimento dos estudantes na escola básica.

\section{Análise de atividade didática à luz das concepções basilares}

Nesta última seção, pretende-se apresentar uma atividade recorrente nas aulas de língua materna, a fim de analisar, à luz das concepções basilares, o porquê de não se fazer o que se faz em aulas de língua portuguesa.

Analisemos o exercício.

Figura 3 - Exercício de Função Sintática

Leia o trecho a seguir e identifique os termos que exercem a função sintática solicitada. A seguir, explique-os.

[...] A Região Sudeste do Brasil é que, historicamente, recebe a maior quantidade de fluxos migratórios do país, principalmente o estado de São Paulo, pelo fato de fornecer maiores oportunidades de emprego em razão do processo de industrialização desenvolvido. [...]

a) Objeto direto do verbo receber

b) Adjunto adnominal do Objeto direto do verbo receber

c) Adjunto adverbial do trecho

Fonte: Acervo pessoal da autora 
Esse exercício faz parte do elenco rotineiro de atividades de gramática, especificamente, de função sintática, apresentados em diferentes materiais didáticos e nas abordagens de sala de aula. Em geral, exercícios desta natureza, solicitam aos estudantes que identifiquem a função sintática de termos destacados. De certa forma, o exercício inova, por solicitar a identificação do termo do trecho, a partir da função sintática (e não o contrário!) que, provavelmente, o professor deseja avaliar. Além dessa identificação, o estudante deve explicar o termo e sua função. Ainda assim, trata-se de um exercício de mera identificação, considerando a cobrança dos termos da tradição gramatical, o que revela uma visão estanque do para quê se deve ensinar e aprender a língua portuguesa em suas diferentes variações.

É preciso esclarecer que o trecho em destaque compõe o último parágrafo de um texto argumentativo sobre a migração interna do Brasil. Portanto, há de se considerar a existência de uma contextualização. Considerando as concepções basilares amplificadas ao longo deste texto, fica claro que o exercício ignora o aspecto central da sociointeração e os conceitos que advêm deste. Tal afirmação é feita porque as tarefas de identificação do objeto direto do verbo, de seus adjuntos adnominais, bem como do adjunto adverbial do trecho podem ser feitas em qualquer trecho verbal, em que se tenha verbo e complemento. Por isso denominou-se como "mera identificação" de termos, cumprindo-se uma tarefa escolar que "cobra" conteúdo específico, mas que ignora aspectos da ação linguajeira que são muito importantes para o entendimento do que é dito no texto de forma explícita e implicitamente.

Considerando as concepções basilares, há alguns elementos muito interessantes no trecho para serem entendidos e não somente serem identificados. É necessário, também, que nossos estudantes entendam o aspecto funcional das escolhas que o enunciador faz para dizer o que deseja dizer.

O sujeito deste primeiro período é “A Região Sudeste do Brasil”. Entretanto, a expressão "o estado de São Paulo" é o sujeito do verbo fornecer. Pode-se afirmar que essa expressão é meronímica em relação à primeira expressão que exerce a função de sujeito de um outro verbo (do primeiro período). Dessa forma, a tessitura deste trecho ocorre pelo 
engendramento existente nessa relação das expressões, que, também, sustenta as causas e as razões apresentadas, ou seja, as circunstâncias no final do trecho do texto argumentativo (Lembre-se de que o exercício oferece o trecho, retirado de um texto maior). Logo, temos uma variedade de adjuntos adverbiais, ou melhor, de circunstâncias no texto:

a) historicamente, principalmente - Adjuntos adverbiais de tempo/modo, em sintagma simples.

b) pelo fato de fornecer maiores oportunidades de emprego - Oração adverbial.

c) em razão do processo de industrialização desenvolvido - Adjunto adverbial em sintagma nominal expandido.

É fundamental, para o pleno entendimento do projeto de dizer do enunciador, que o leitor perceba este jogo discursivo. A pergunta que fica é qual será a resposta a ser considerada correta, adequada, pelo docente, na correção do item (c). É importante, ainda, que o estudante entenda a função discursiva do uso do lexema historicamente. Ao utilizá-lo, pode-se entender uma crítica, mostrando que, neste fluxo migratório brasileiro, a região sudeste recebe, há muito, os migrantes por ser mais desenvolvida em relação às demais regiões brasileiras.

Outro ponto importante a ser discutido é a posição da expressão que tem a função de sujeito em comparação com a posição da expressão que exerce a função de objeto direto. Ao se iniciar o texto com a sintagma nominal "A Região Sudeste do Brasil”, tem-se uma intenção comunicativa, central no trecho que traz a valoração da região. Se o período fosse escrito da seguinte forma: "A maior quantidade de fluxos migratórios do país é recebida, historicamente, pela Região sudeste do Brasil", teríamos uma mudança na ordem sintática do período, o que implicaria na mudança da informação tópica do trecho, possivelmente, modificando a intenção comunicativa do enunciador, agora, na reescrita, centrada no fluxo migratório, propriamente dito. Portanto, mais do que identificar a função ou seu termo, é importante saber qual o impacto discursivo das escolhas orquestradas pelo enunciador no texto. 
Em relação ao adjunto adnominal do complemento do verbo receber, há dois pontos que merecem consideração: a) $\mathrm{O}$ objeto direto é "a maior quantidade de fluxos migratórios do país". b) qual é o núcleo do objeto direto: quantidade? Fluxos? Porque pode-se dizer assim: recebe quantidade ... Ou recebe fluxos.... Em uma ou outra opção, temos projeções discursivas diferentes que mudam a relação termo nuclear e termo adjunto. Além disso, acredita-se que seja difícil afirmar qual é, de fato, a escolha do enunciador exatamente, ou seja, qual é o núcleo e quais os adjuntos, já que se tem um sintagma nominal longo. A meu ver não há o certo ou o errado. Portanto, cabem duas diferentes respostas no exercício item (b).

A análise do exercício nos oportuniza concretizar o que se pensa sobre as práticas didáticas decorrentes em aulas de língua portuguesa nos diferentes anos de escolaridade do nível básico. Deseja-se salientar, ainda, que, a partir de um pequeno trecho de um texto, considerando sua tessitura, tem-se a oportunidade de desenvolver as necessárias habilidades de leitura. É para isto que serve a gramática! Para nos fazer, como leitores, sermos capazes de entender um texto. A par disso, ao se entender, ao se discutir, ao se ressignificar o texto, estamos ampliando nosso capital de recursos linguístico- discursivos, o que, sem dúvida, auxilia no desenvolvimento de habilidades de escrita. Por isso, a relação leitura/ escrita / gramática tem de ser o mote principal do currículo programático de Língua Portuguesa, tomando as diretrizes teóricas dos conceitos basilares, conforme aqui preconizado.

\section{Conclusão}

É preciso assumir que não se trata de um tema novo dentro da área de linguagem. Também é preciso dizer que não se está, de forma alguma, culpando os docentes, especialistas, os coordenadores pedagógicos das escolas ou as próprias escolas. Ainda é preciso afirmar que não há culpados.

Há tendências. Há dificuldades. Há entraves na relação das Universidades, dos Cursos de formação de professores, pois as informações não conseguem chegar à ponta. $\mathrm{O}$ que se tem são muitos professores recém-saídos dos bancos universitários, mas que não 
têm experiência de sala de aula. Há outros tantos docentes que têm muita experiência na sala de aula, mas não têm contato mais estreito com as novas teorias.

É preciso investir muito em formação dos professores. Há de se pensar no como estas formações devem ser realizadas. Essas formações não podem ser vistas como a "varinha de condão" metodológica. Não pode ser! Precisam embasar as escolhas que o docente precisa fazer para desenvolver as habilidades de leitura e de escrita de seus estudantes em suas diferentes realidades.

Por fim, sabe-se que para toda a tarefa de compreensão, seja qual for a extensão do texto, o conhecimento prévio do leitor, bem como o conhecimento dos conceitos abrem caminhos para o entendimento do texto. Tomemos a escola como o nosso contexto, nosso currículo programático como texto, a sala de aula como gênero textual e docente e estudantes como enunciadores. Tratemos as diferentes situações didáticas como situações linguajeiras (Que o são!) e façamos a mediação desse processo para o pleno desenvolvimento da competência discursiva de nossos alunos, tendo como sustentáculo fundamental as concepções basilares da linguagem.

\title{
BASILAR CONCEPTIONS AND TEACHING PRACTICES IN PORTUGUESE LANGUAGE CLASSES
}

\begin{abstract}
The challenge of basic education, in the middle of the 21st century, is, in fact, to make our students leave the school mastering basic knowledge. We always listen that Brazilian students know nothing; large-scale assessments have different results throughout the year, attest the common sense: the extreme difficulties of student's education. The Portuguese Language and Mathematics lead in results below the desirable of the students. We cannot deny the efforts, even if sheepish, engendered by the MEC and by different education departments. The crucial question is why the Brazilian results continue to denounce the student's serious difficulties. As a Portuguese language teacher and teacher trainer, I also address this serious problem. My central hypothesis is that the difficulties are not just a methodological issue or a lack of courseware. These will be achieved by the clear absence of theoretical assumptions that support the practices of teaching and learning Portuguese in the formality of the classroom. Taking this hypothesis as a starting point for the reflections I wish to propose in this paper, I intend to discuss the mistakes found in different didactic practices, considering fundamental linguistic concepts, such as: the concepts of langue and language, specifically, língua and linguagem, in portuguese, the concept of text and the of genres. It is postulated that, despite of the great and important advance of linguistic theories, these concepts do not reach the end: the basic classroom and the teacher of basic education.
\end{abstract}

KEYWORDS: Basilar conceptions; classroom's practice; linguistic theories; Social Interaction. 


\section{REFERÊNCIAS}

BAKHTIN, Mikhail. Os gêneros do discurso. In: Estética da criação verbal. Tradução Paulo Bezerra. 6.ed. São Paulo: Martins Fontes, 2011.

BRASIL. Base Nacional Comum Curricular. Educação é a base. Brasília, Secretaria de educação Fundamental. MEC, 2018.

BRASIL. Parâmetros Curriculares Nacionais — terceiro e quarto ciclos do ensino fundamental: língua portuguesa. Brasília, Secretaria de Educação Fundamental. MEC, 1998.

FÁVERO, Leonor; KOCH, Ingedore. Linguistica textual: introdução. São Paulo: Contexto, 1983.

FRANCO, Luiz Gustavo; MUNFORD, Denise. Reflexões sobre a Base Nacional Comum Curricular: Um olhar da área de Ciências da Natureza. Horizontes, v. 36, n. 1, p. 158-170, jan./abr. 2018.

GERALDI, João W.(org.) O texto na sala de aula. São Paulo: Ática, 2012.

KLEIMANN, Angela. Oficina de leitura: teoria \& prática. 11. ed., Campinas, SP: Pontes, 2007.

KOCH, Ingedore Villaça Grünfeld. A inter-ação pela linguagem. 11. ed., São Paulo: Contexto, 2014.

SANTOS, Leonor Werneck. O ensino de língua portuguesa: PCN e livros didáticos em questão. Revista Diadorim, V. 6. p. 55- 68, 2009.

TRAVAGLIA, Luiz Carlos. Gramática e interação: Uma proposta para o ensino de gramática no primeiro e segundo grau. São Paulo: Ed. Cortez, 1997.

Recebido em: 02/05/2020.

Aprovado em: 03/06/2020. 